\title{
O PROCESSO PROJETUAL DO DESIGN DE INTERIORES E A INTEGRAÇÃO DOS PRINCÍPIOS DA SUSTENTABILIDADE; FOCO NA DIMENSÃO ECONÔMICA
}

\author{
PEDRO ROCHA SOUSA FILHO | UFMA \\ ANA LÚCIA ALEXANDRE DE OLIVEIRA ZANDOMENEGHI, PhD. |UFMA
}

\section{RESUMO DE PESQUISA DISSERTATIVA}

A sustentabilidade se apresenta na atualidade como uma temática imprescindível devido às evidências do limite do planeta. Deste modo, uma economia pautada no crescimento pelo aumento do consumo de recursos naturais talvez seja uma das principais questões que agrave o aquecimento global. Assim, no planejamento de ambientes internos no âmbito do design de interiores, o profissional da área pode assumir importante papel educacional para uma consciência no uso e redução do consumo de recursos naturais e impactos ambientais na natureza. Além disso, também é capaz de contribuir na promoção do desenvolvimento local no processo projetual para uma economia mais igualitária; beneficiando a dimensão econômica da sustentabilidade por meio da prática de seus princípios, que são: fortalecer e valorizar recursos locais; respeitar e valorizar a cultura local; promover a economia local; promover organizações em rede; valorizar a reintegração de resíduos, e; promoção da educação para a economia sustentável (SANTOS et al., 2019). Entretanto, faz-se necessário analisar a forma que o profissional compreende e integra tais princípios em seus projetos, visando garantir a sua habilitação para o viés da valorização e defesa de uma economia justa e ética. Portanto, o estudo conteve o objetivo de investigar a integração dos princípios da dimensão econômica da sustentabilidade no processo projetual dos designers de interiores por meio da pergunta de pesquisa: como os designers de interiores integram e aplicam os princípios da dimensão econômica da sustentabilidade em suas práticas projetuais? Para o alcance da resposta, definiu-se os objetivos específicos: (a) analisar a aplicação de princípios da dimensão econômica da sustentabilidade no processo projetual dos designers de interiores; (b) identificar estratégias de integração de princípios da dimensão econômica da sustentabilidade no processo projetual dos designers de interiores; (c) criar recomendações para integração de princípios da dimensão econômica da sustentabilidade no processo projetual dos designers de interiores. Neste alinhamento, sendo a mesma de natureza qualitativa e características exploratória / descritiva, o procedimento metodológico adotou como escopo para coleta de informações a pesquisa teórica, apoiada pela Revisão Bibliográfica Sistemática - RBS (CONFORTO, AMARAL e SILVA, 2011), a aplicação de questionário on-line, que obteve a participação de 96 (noventa e seis) respondentes da cidade de São Luís - Maranhão, em 2019; e a técnica de grupo focal, com a participação de 7 (sete) pessoas. Os referidos dados analisados por meio da triangulação metodológica (YIN, 2005) permitiram reunir uma base teórico-prática imprescindível para a síntese do estudo. Como conclusão da pesquisa, verificou-se a falta de compreensão e a pouquíssima integração dos princípios da dimensão econômica da sustentabilidade no processo projetual entre os profissionais. Consequentemente, inteirando o objetivo geral: propor recomendações que integrem e operacionalizem os princípios da dimensão econômica da sustentabilidade no processo projetual dos designers de interiores; foi possível propor um conjunto de 15 (quinze) recomendações para a integração e a operacionalização dos princípios da dimensão econômica da sustentabilidade no processo projetual dos profissionais. Estas recomendações propostas constituem ações que podem ser acionadas por meio das estratégias de operacionalização dentro do processo projetual pelos profissionais que atuam no design de interiores, e, assim, contribuírem para o desenvolvimento econômico local, além da redução de impactos ambientais em suas atividades.

\section{REFERÊNCIAS}

CONFORTO, Edivandro Carlos; AMARAL, Daniel; SILVA, Sérgio Luis da. Roteiro para revisão bibliográfica 
sistemática: aplicação no desenvolvimento de produtos e gerenciamento de projetos. In: $8^{\circ}$ Congresso Brasileiro de Gestão e Desenvolvimento de Produto (CBGDP), Porto Alegre - RS, 2011.

SANTOS, Aguinaldo dos et al. Design para a sustentabilidade: dimensão social. Curitiba, PR: Insight, 2019. YIN, R. K. Estudo de caso: planejamento e métodos. Porto Alegre: Bookman, 2005 